\title{
The forgotten tale of immunoglobulin allotypes in cancer risk and treatment
}

\author{
Janardan P Pandey ${ }^{1,2^{*}}$ and Zihai $\mathrm{Li}^{1,2}$
}

\begin{abstract}
Monoclonal antibody (mAb) has fulfilled the promise of being the "Magic Bullet" in oncology with the clinical success of mAbs against CD20, Her-2/neu, epidermal growth factor receptor, vascular endothelial cell growth factor and others in a variety of cancers. Most manufacturers of mouse-human chimeric antibodies (and most immunologists) have treated the constant region of human immunoglobulin (Ig) as if it were naturally monomorphic and therefore not immunogenic in humans. In fact, the constant region of Ig heavy and light chain is highly polymorphic, and yet Ig haplotypes are usually not defined by genome-wide association studies nor are they considered to be important for optimizing mAb therapy. We hereby summarize evidence that Ig allotypes are important and biologically relevant in that they contribute to the etiopathogenesis of many malignant, infectious, and autoimmune diseases. Because Ig allotypes differ from each other in engaging Fc receptor, we argue that future development of effective mAb therapy for cancer should take a patient-specific approach by using the correct allotype for each patient to maximize the efficacy of this therapy.
\end{abstract}

Keywords: GM and KM allotypes, IGHG genes, ADCC, CDC, Isoallotypes, Immunosurveillance, GVL

\section{Introduction}

Though any genetic variant of a protein could be called an allotype, in immunology, the term is commonly used for hereditary antigenic determinants expressed on immunoglobulin (Ig) polypeptide chains. Allotypes are encoded by autosomal codominant genes that follow Mendelian laws of heredity. With one exception [1], allotypes identified thus far are expressed on the constant $(C)$ region of $\operatorname{IgG}, \operatorname{Ig} A$, and IgE heavy chains and on $\mathrm{k}$-type light chains [2]. In this minireview, we will focus primarily on GM (genetic markers of $\gamma$ chain) and KM (genetic markers of $\mathrm{k}$ chain) allotypes (Figure 1).

\section{GM allotypes}

GM allotypes are encoded by three very closely linked and highly homologous genes-Ig heavy chain G1 (IGHG1), IGHG2, and IGHG3-on chromosome 14q32. There are two systems of GM gene nomenclature currently in use-alphameric and numeric. We have provided both. In accordance with the international

\footnotetext{
* Correspondence: pandeyj@musc.edu

'Department of Microbiology and Immunology, Medical University of South Carolina, Charleston, SC, USA

${ }^{2}$ Hollings Cancer Center, Medical University of South Carolina, Charleston, SC 29466, USA
}

system for human gene nomenclature, haplotypes and genotypes/phenotypes are written by grouping together the markers that belong to each subclass, by the numerical order of the marker and of the subclass; markers belonging to different subclasses are separated by a space, while allotypes within a subclass are separated by commas. There are currently 18 serologically testable GM specificities-four on $\gamma 1(1 / \mathrm{a}, 2 / \mathrm{x}, 3 / \mathrm{f}, 17 / \mathrm{z})$, one on $\gamma 2(23 / \mathrm{n})$, and 13 on $\gamma 3(5 / \mathrm{b} 1,6 / \mathrm{c} 3,10 / \mathrm{b} 5,11 / \mathrm{b} 0,13 / \mathrm{b} 3$, 14/b4, 15/s, 16/t, 21/g1, 24/c5, 26/u, 27/v, 28/g5). With the exception of allelic GM3 and GM17 determinants expressed in the Fd region (the Fab portion of heavy chain), all other GM alleles are expressed in the Fc region of $\gamma$ chains. Linkage disequilibrium (non-allelic association) in the GM system within a racial group is almost absolute and the determinants are transmitted as a group-haplotypes. Each major race has a distinct array of several GM haplotypes. GM 323 5,10,11,13,14,26 and GM 1,17 5,10,11,13,14,17,26 are examples of common Caucasian and Negroid haplotypes, respectively. Unless there is genetic admixture, these two groups do not share any haplotypes. Nucleotide substitutions (SNPs) responsible for most of the 18 serologically detectable GM specificities have not yet been identified. Serological 


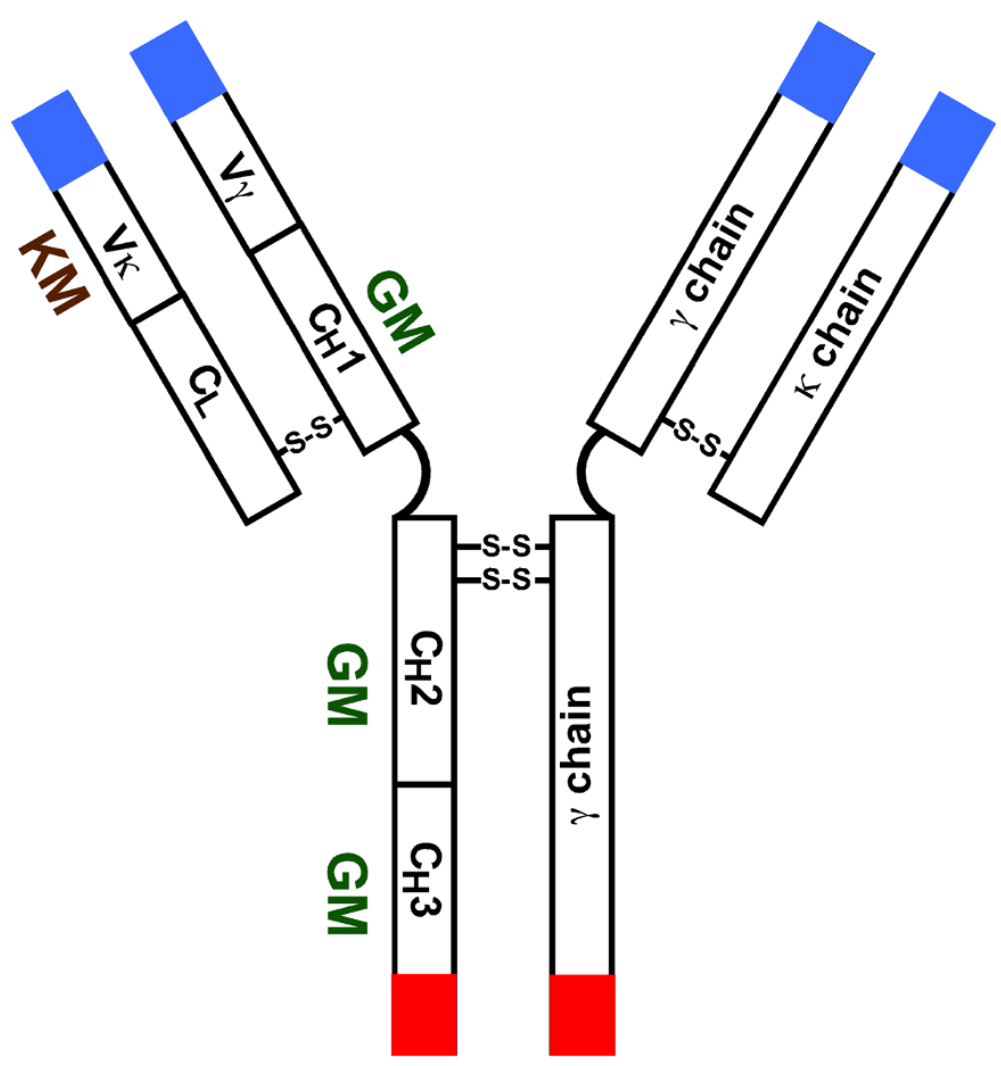

Figure 1 Localization of GM and KM allotypes on IgGk molecule.

reagents for GM typing are either extremely scarce or not available at all. Molecular methods for determining some GM markers are available; we, and others, are currently developing DNA-based methods for other markers.

\section{Isoallotypes}

These are markers that behave as alleles in one IgG subclass (allotypes) but are also expressed in all molecules of at least one other subclass (isotype). For instance, human $\gamma 4$ chains, unlike other $\gamma$ chains, do not express unique allotypes, but they do express isoallotypes. These isoallotypes may be functionally involved in the so-called "Fab arms exchange" between IgG4 antibodies, an immunological mechanism implicated in the antiinflammatory activity of these antibodies [3]. The arginine/lysine substitution at amino acid position 409 (R409/ K409) of $\gamma 4$, characterizes an isoallotype [4]. R409 and K409 behave as alleles on $\gamma 4$ (allotypes), but they are also present on all molecules of the other $\gamma$ chains (isotypes). R409 enables the Fab arms exchange, while K409 blocks it [5]. Thus, examination of $\gamma$ allotypes and isoallotypes may shed light on the etiology of IgG4-mediated diseases [6].

\section{GM allotypes and disease susceptibility}

The marked differences in the frequencies of GM allotypes among races, strong linkage disequilibrium within a race, and racially-restricted occurrence of GM haplotypes, all suggest that differential selection over many generations may have played an important role in the maintenance of polymorphism at these loci. As first suggested by J.B.S. Haldane, major infectious diseases have been the principal selective forces of natural selection [7]. Malignant diseases, however, might also have exerted adaptive pressure on GM polymorphisms. Since most cancers (breast, prostate, etc.) occur predominantly in middle and older age groups, it is commonly suggested that they may not be subject to natural selection because people with these diseases are beyond their reproductive age. However, the predominant occurrence of cancer in the older age groups may reflect the multistep nature of cancer development rather than the lack of evolutionary adaptive pressure [8].

Using hypothesis driven candidate gene approaches, numerous studies have identified particular GM genes as risk factors for many malignant [9-13], infectious [14-18], and autoimmune diseases [19-24], but most of these findings have not been confirmed or refuted by modern genome-wide association studies (GWAS). One contributing factor might be the absence of GM gene probes in most genotyping platforms. GWAS are assumed to be able to detect/tag all SNPs in the genome whose frequency is at least $5 \%$ or less (using newer 
arrays). This, however, is not true. Most GM alleles are common within a racial group (some with gene frequency $>70 \%$ ), but the IGHG gene segments harboring them are highly homologous and apparently not amenable to the high throughput genotyping technology used in GWAS. Because these genes were not typed in the HapMap project, they cannot be imputed or tagged (through linkage disequilibrium) by any SNPs that are included in the genotyping platforms. One of us (J.P.P.) has stressed the importance of GM genes in human biology and pointed out that they are not being evaluated by GWAS in letters to some high-profile journals [25-28], hoping to reach a wide audience. It is encouraging to note that a recent GWAS of multiple sclerosis did include GM alleles and concluded that particular GM haplotypes contributed to the higher IgG levels in the cerebrospinal fluid of these patients [29]. Using a candidate gene approach, we came to the same conclusion over three decades ago [30].

\section{Possible mechanisms underlying the involvement of GM genes in the etiopathogenesis of human diseases}

Several immunological mechanisms, which are not mutually exclusive, can be postulated to explain GM gene involvement in various human diseases.

\section{GM allotypes and immune response to self and non-self antigens}

GM allotypes could mediate the development or progression of a disease by influencing the immune responsiveness to the antigens relevant to the disease. Importance of Ig allotypes in controlling immune responsiveness was recognized over 40 years ago [31]. More recent studies have shown that immune responsiveness to a variety of antigens-infectious agents, vaccines, autoantigens, including some tumor-associated antigens, are associated with particular GM and KM (see below) allotypes [14,32-39]. We have recently reported the contribution of these genes to antibody responses to the tumor-associated antigens mucin 1 and human epidermal growth factor receptor 2 (HER2) [40-43].

GM markers could influence antibody responsiveness to disease-associated antigens by being part of the recognition structure for these antigens on the B-cell membrane-bound IgG. Membrane-bound IgG molecules expressing different GM specificities may have differential affinity to antigenic epitopes, resulting in stronger/ weaker humoral immunity to particular antigens. Alternatively, these $\mathrm{C}$-region determinants could influence the conformation of the Ig variable $(\mathrm{V})$ regions involved in antigen binding and thus cause changes in antibody affinity and specificity. Studies in mice investigating the contribution of C-region determinants to the expression of certain idiotypes and their participation in other conformational changes in the $\mathrm{V}$ region support this interpretation. Involvement of both $\mathrm{C}$ and $\mathrm{V}$ regions in the formation of idiotypic determinants was documented many years ago [44]. Recent investigations by Casadevall and his colleagues have clearly established that the $\mathrm{C}$ region contributes to the affinity and specificity of antibodies [45]. Relevant to the present discussion, they have shown that amino acid sequence polymorphisms in the $\mathrm{C}$ region of the Ig molecule affect the secondary structure of the antigen-binding site in the $\mathrm{V}$ region [46]. Amino acid substitutions associated with GM allotypes cause structural changes in the $\mathrm{C}$ region, which could impose structural constraints (conformation) on the $\mathrm{V}$ region, resulting in variation in antibody affinity and specificity. Thus, $C$ regions expressing different GM allotypes, even when combined with identical $\mathrm{V}$ region sequences, can generate new antibody molecules with new functions.

\section{GM allotypes and antibody-dependent cell- mediated cytotoxicity (ADCC)}

ADCC, which links the innate and the adaptive arms of immunity, is a major host immunosurveillance mechanism against tumors, as well as the leading mechanism underlying the clinical efficacy of therapeutic antibodies such as cetuximab and trastuzumab, which target tumor antigens, HER1 and HER2, respectively. IgG antibody mediated ADCC is triggered upon ligation of Fcy receptor $(\mathrm{Fc} \gamma \mathrm{R})$ to the $\mathrm{Fc}$ region of IgG molecules. It follows that genetic variation in $\mathrm{Fc} \gamma \mathrm{R}$ and $\mathrm{Fc}$ could contribute to the differences in the magnitude of ADCC. Several studies have shown that genetic variation in $\mathrm{Fc} \gamma \mathrm{R}$ contributes to the differences in the magnitude of ADCC [47-50], but with the exception of our studies, the contribution of natural genetic variation in the Fc region of IgG-GM allotypes-has not been investigated. Using an ADCC inhibition assay, we have shown that IgG1 expressing the GM 3+,1-,2- allotypes was equally effective in inhibiting cetuximab- and trastuzumab-mediated ADCC of respective target cells, in the presence of NK cells expressing either valine or phenylalanine allele of FcyRIIIa [51]. These findings have important implications for engineering antibodies with human $\gamma 1 \mathrm{C}$ region. Concerted effort is currently being directed at engineering Fc variants with optimized affinity for activating and inhibiting FcyRs [52-54]. Evaluation of the role of naturally occurring Fc (GM) variants that may have been evolutionarily selected because of their contribution (through ADCC and other protective immunosurveillance mechanisms) to survival from malignant diseases [8] is essential for engineering the next generation of humanized monoclonal antibodies, which have reduced immunogenicity, have better clinical efficacy, and benefit more 
patients than what is possible with the currently available therapeutics.

\section{GM allotypes and complement-dependent cytotoxicity (CDC)}

The complement system plays an important role in immunosurveillance, and CDC has been shown to be instrumental in the efficacy of certain mAbs, such as rituximab (anti-CD20) and alemtuzumab (anti-CD52). Though not yet investigated, there is a good rationale for the involvement of GM alleles in CDC as well. In $\mathrm{CDC}, \mathrm{C} 1 \mathrm{q}$ binds the antibody and triggers the complement cascade. C1q's binding affinity to the antibody molecules is likely to affect the level of CDC against tumor cells. It has been known for some time that $\mathrm{C} 1 \mathrm{q}$ discriminates between two major alleles of IgG3: It binds slightly better to IgG3 proteins expressing the GM21 allele than to those expressing the alternative GM5 allele [55]. It follows that IgG3 mAbs expressing the GM21 allele in their Fc would be more effective in CDC against cancer cells.

\section{GM allotypes and viral immunoevasion}

Several viruses have been implicated in the etiopathogenesis of malignant diseases, and the list of virally-induced/spurred cancers is growing steadily. To ensure their survival, viruses must be able to enfeeble the defense mechanisms employed by the host's immune system to eliminate the virions and virally infected cells (immunosurveillance). During the coevolution of viruses and their hosts, the host must have evolved specific mechanisms to modulate the effects of these viral strategies and ensure our survival as a species. A clue to one such mechanism is offered by studies involving GM allotypes and human cytomegalovirus (HCMV), which is implicated in gliomas [56], and hepatitis C virus (HCV), a well-known etiological agent for liver cancer.

HCMV has evolved a large repertoire of immune evasion strategies. One strategy involves generating two proteinsencoded by genes TRL11/IRL11 and UL119-UL118-that have functional properties of the Fc $\gamma \mathrm{R}$ [57], which may enable the virus to evade host immunosurveillance by evading the effector consequences of antibody binding, such as $\mathrm{ADCC}, \mathrm{CDC}$, and phagocytosis. We have recently shown that GM alleles modulate this viral strategy: the HCMV TRL11/IRL11-encoded Fc $\gamma \mathrm{R}$ has significantly higher affinity for IgG1 proteins expressing the GM 3+, 1-,2- allotypes than for those expressing the allelic GM $17+, 1+, 2+$ allotypes [58]. Because of their higher affinity to the HCMV-encoded FcyR, anti-HCMV IgG1 antibodies expressing the GM 3+,1-,2- allotypes would be more likely to have their Fc domains scavenged, thereby reducing their immunological competence to eliminate the virus through Fc-mediated effector mechanisms. Consequently, the frequency of these allotypes would be expected to be higher in patients with HCMVinduced/spurred diseases. This appears to be the case in glioma (manuscript under review). Another herpes virus, herpes simplex virus type 1 (HSV1), also encodes for immune-evading $\mathrm{Fc} \gamma \mathrm{R}$ proteins that discriminate between GM alleles [59]. However, the HCMV- and HSV1-encoded Fc $\gamma$ Rs have contrasting binding affinities to allelically disparate IgG1 antibodies, making the particular alleles relevant to the etiology of HCMV- or HSV1-spurred diseases. Similarly, the HCV core protein, which also displays the functional properties of the $\mathrm{Fc} \gamma \mathrm{R}$, binds differentially to IgG proteins expressing different allotypes [60-62], making these allotypes relevant to the etiology of $\mathrm{HCV}$-induced liver cancer.

\section{Immunoglobulin KM allotypes}

Like the $\gamma$ chains, the $\kappa$ chain is also polymorphic, characterized by the segregation of three alleles-KM1, KM1,2, and KM3 on chromosome 2p12 [2]. Over 98\% of the people positive for the KM1 allotype are also positive for KM2; the KM1 allele, without KM2, is extremely rare. These alleles represent amino acid substitutions at positions 153 and 191 of $\mathrm{k}$ chain-KM1: valine 153, leucine 191; KM1,2: alanine 153, leucine 191; and KM3: alanine 153, valine 191 .

Though virtually ignored so far, KM alleles are likely to become important in cancer immunology research, thanks to a major genomics study [63]. This comprehensive analysis of human gene expression identified IGKC as a novel prognostic marker in several solid tumors. The IGKC as a single marker had as much effect on metastasis-free survival as the 60 genes in the B-cell plasma cell metagene. This is not surprising since the $\mathrm{K}$ chain can pair with the Ig heavy chains of all classes and subclasses. Although the authors could not address the biological roles of the IGKC signature, their results provide a compelling rationale for investigating the role of $\mathrm{KM}$ alleles, genetic variants of $I G K C$, in humoral immunity to tumor-associated antigens. It is relevant to note that several years ago we noted an increased frequency of the KM1 allele in patients with head and neck cancer [64]. Examination of KM alleles would be especially important in malignancies characterized by racial disparity, such as prostate cancer, since KM gene frequencies differ significantly among various racial groups [2].

It would also be important to investigate possible interactive effects of GM and KM alleles in disease susceptibility, in immune responsiveness to tumor antigens, and in patient survival after therapy. Although immunology textbooks state that heavy and light chains pair randomly to produce Ig molecules, some studies in experimental animals have provided evidence for preferential pairing of these polypeptide chains $[65,66]$. 
Thus $\gamma$ and $\kappa$ chains expressing particular GM and KM alleles could preferentially associate to generate an IgG antibody directed against an antigen. We have shown such interactive effects of GM and KM alleles in humoral immunity to Epstein-Barr virus [67], group B streptococcus antigens [68], HCV envelope proteins E1 and E2 [32], and mucin 1 [40].

\section{KM allotypes and graft versus leukemia (GVL)}

KM allotypes appear to be relevant to hematological malignancies. Since they are expressed on B cells, they are potential minor histocompatibility antigens and could be targets for the GVL phenomenon when hematopoietic cell transplant (HCT) recipients and donors express different KM alleles. Results of a study from Australia support this contention [69]. In this study, HLA-matched Caucasian donors and recipients of HCT for B-cell malignancies were typed for KM alleles to determine whether or not KM disparity influenced the HCT outcome. KM allotype disparity between transplant pairs was associated with increased survival compared with pairs that were not mismatched. More such studies are needed, especially in African Americans where KM1 allele frequency is significantly higher than that in Caucasians.

\section{GM and KM allotypes and development of resistance to monoclonal antibody therapy}

The response rate to most mAbs is low and all patients eventually develop resistance to this therapy. Numerous mechanisms of resistance have been proposed but they do not account for the total inter-individual variation in treatment responses in de novo and in acquired resistance, which suggests involvement of additional mechanisms. One potential mechanism that has not received adequate attention is the role of anti-allotype antibodies. All licensed chimeric or humanized mAbs express certain GM allotypes on their heavy chains and KM allotypes on their $\mathrm{k}$ light chains. For instance, trastuzumab expresses GM17 and KM3 and cetuximab expresses GM3 and KM3. Most GM/KM determinants are highly immunogenic, and the Ig molecules carrying these markers cross the maternal-fetal barrier in both directions, leading to anti-GM/KM antibody production in the mother against the paternal GM/KM markers present in the child, and in the child against the maternal GM/KM alleles [70]. Patients who lack the GM/KM allotypes present on the mAbs would be expected to generate antibodies to these determinants if exposed through maternal-fetal incompatibility, allotype-incompatible blood transfusion or infusion of the mAbs. These preexisting or mAbs-induced anti-allotype antibodies and the administered mAbs could form immune complexes that would be eliminated by phagocytic cells, leading to nonresponsiveness. At present, no data are available on the prevalence of anti-allotype antibodies in patients treated with mAbs.

In summary, inclusion of polymorphic GM, KM, and $\mathrm{Fc} \gamma \mathrm{R}$ alleles in cancer immunology investigations could identify novel immune pathways to tumor immunity. This knowledge would be helpful in diagnosis, prognosis, and in devising effective immunotherapeutic strategies against cancer. At present, a candidate gene approach would be necessary for these studies, since these genes (GM in particular), are not included in most genotyping arrays used in GWAS. Furthermore, GWAS, in general, do not measure epistasis (gene-gene interaction), which probably accounts for a significant portion of the "missing" heritability in complex diseases.

\section{Competing interests}

The authors declare that they have no competing interests.

\section{Authors' contributions}

JPP and ZL wrote the manuscript. Both authors read and approved the final manuscript.

Received: 11 January 2013 Accepted: 13 February 2013

Published: 20 February 2013

\section{References}

1. Wang AC, Mathur S, Pandey JP, Siegal FP, Middaugh CR, Litman GW: Hv (I), a variable-region genetic marker of human immunoglobulin heavy chains. Science 1978, 200:327-329.

2. Lefranc MP, Lefranc G: Human Gm, Km, and Am allotypes and their molecular characterization: a remarkable demonstration of polymorphism. Methods Mol Biol 2012, 882:635-680.

3. van der Neut KM, Schuurman J, Losen M, Bleeker WK, Martínez-Martínez P, Vermeulen E, den Bleker TH, Wiegman L, Vink T, Aarden LA, De Baets MH, van de Winkel JG, Aalberse RC, Parren PW: Anti-inflammatory activity of human IgG4 antibodies by dynamic Fab arm exchange. Science 2007, 317:1554-1557.

4. Brusco A, Saviozzi S, Cinque F, DeMarchi M, Boccazzi C, de Lange G, van Leeuwen AM, Carbonara AO: Molecular characterization of immunoglobulin G4 gene isoallotypes. Eur J Immunogenet 1998, 25:349-355.

5. Labrijn AF, Rispens T, Meesters J, Rose RJ, den Bleker TH, Loverix S, van den Bremer ET, Neijssen J, Vink T, Lasters I, Aalberse RC, Heck AJ, van de Winkel $J G$, Schuurman J, Parren PW: Species-specific determinants in the IgG $\mathrm{CH} 3$ domain enable Fab-arm exchange by affecting the noncovalent $\mathrm{CH} 3-$ CH3 interaction strength. J Immunol 2011, 187:3238-3246.

6. Pandey JP: Genetic markers of IgG as potential risk factors for lgG4related disease. J Rheumatol 2048, 2012:39.

7. Lederberg J: J.B.S. Haldane (1949) on infectious disease and evolution Genetics 1999, 153:1-3.

8. Klein G: Toward a genetics of cancer resistance. Proc Natl Acad Sci USA 2009, 106:859-863.

9. Nakao Y, Matsumoto H, Miyazaki T, Watanabe S, Mukojima T, Kawashima R, Fujita T, Tsuji K: Immunoglobulin G heavy-chain allotypes as possible genetic markers for human cancer. J Natl Cancer Inst 1981, 67:47-50.

10. Pandey JP, Ebbesen P, Bulow S, Svendsen LB, Fudenberg HH: IgG heavychain (Gm) allotypes in familial polyposis coli. Am J Hum Genet 1986, 39:133-136.

11. Pandey JP, Johnson AH, Fudenberg HH, Amos DB, Gutterman JU, Hersh EM: $\mathrm{HLA}$ antigens and immunoglobulin allotypes in patients with malignant melanoma. Hum Immunol 1981, 2:185-190.

12. Hić V, Milosević-Jovcić N, Marković D, Petrović S, Stefanović G: A biased Gm haplotype and $\mathrm{Gm}$ paraprotein allotype in multiple myeloma suggests a role for the $\mathrm{Gm}$ system in myeloma development. Int J Immunogenet 2007, 34:119-125. 
13. Pandey JP, Kistner-Griffin E, Iwasaki M, Bu S, Deepe R, Black L, Kasuga Y, Hamada GS, Tsugane S: Genetic markers of immunoglobulin G and susceptibility to breast cancer. Hum Immunol 2012, 73:1155-1158.

14. Pandey JP: Immunoglobulin GM and $\mathrm{KM}$ allotypes and vaccine immunity. Vaccine 2001, 19:613-617.

15. Pandey JP, Astemborski J, Thomas DL: Epistatic effects of immunoglobulin GM and KM allotypes on outcome of infection with hepatitis $C$ virus. J Virol 2004, 78:4561-4565.

16. Granoff DM, Boies E, Squires J, Pandey JP, Suarez B, Oldfather J, Rodey GE: Interactive effect of genes associated with immunoglobulin allotypes and HLA specificities on susceptibility to Haemophilus influenzae disease. J Immunogenet 1984, 11:181-188.

17. de Vries RRP, Meera Khan P, Bernini LF, van Loghem E, van Rood J: Genetic control of survival in epidemics. J Immunogenet 1979, 6:271-287.

18. Deepe RN, Kistner-Griffin E, Martin JN, Deeks SG, Pandey JP: Epistatic interactions between Fc (GM) and FcyR genes and the host control of human immunodeficiency virus replication. Hum Immunol 2012, 73:263-266

19. Pandey JP, Cooper GS, Treadwell EL, Gilkeson GS, St Clair EW, Dooley MA: Immunoglobulin GM and KM allotypes in systemic lupus erythematosus. Exp Clin Immunogenet 2001, 18:117-122.

20. Pandey JP, Goust JM, Salier JP, Fudenberg HH: Immunoglobulin G heavy chain (Gm) allotypes in multiple sclerosis. J Clin Invest 1981, 67:1797-1800.

21. Gilhus NE, Pandey JP, Gaarder PI, Aarli JA: Immunoglobulin allotypes in myasthenia gravis patients with a thymoma. J Autoimmun 1990, 3:299-305.

22. Dugoujon JM, Cambon-Thomsen A: Immunoglobulin allotypes (GM and KM) and their interactions with HLA antigens in autoimmune diseases: a review. Autoimmunity 1995, 22:245-260.

23. Kagnoff MF, Weiss JB, Brown RJ, Lee T, Schanfield MS: Immunoglobulin allotype markers in gluten-sensitive enteropathy. Lancet 1983, 1:952-953.

24. Galbraith GMP, Thiers BH, Pandey JP: Gm allotype associated resistance and susceptibility to alopecia areata. Clin Exp Immunol 1984, 56:149-152.

25. Pandey JP: Genetic polymorphism of Fc. Science 2006, 311:1376-1377.

26. Pandey JP: Candidate gene approach's missing link. Science 2010, 329:1148.

27. Pandey JP: Genomewide association studies and assessment of risk of disease. N Engl J Med 2010, 363:2076-2077.

28. Pandey JP: Risk alleles in idiopathic membranous nephropathy. N Engl J Med 2073, 2011:364

29. Buck D, Albrecht E, Aslam M, Goris A, Hauenstein N, Jochim A, International Multiple Sclerosis Genetics Consortium, Wellcome Trust Case Control Consortium, Cepok S, Grummel V, Dubois B, Berthele A, Lichtner P, Gieger C, Winkelmann J, Hemmer B: Genetic variants in the immunoglobulin heavy chain locus are associated with the lgG index in multiple sclerosis. Ann Neurol 2013, 73:86-94

30. Salier JP, Goust JM, Pandey JP, Fudenberg HH: Preferential synthesis of the $\mathrm{G} 1 \mathrm{~m}(1)$ allotype of $\mathrm{IgG} 1$ in the central nervous system of multiple sclerosis patients. Science 1981, 213:1400-1402.

31. Lieberman R, Stiffel C, Asofsky R, Mouton D, Biozzi G, Benacerraf B: Genetic factors controlling anti-sheep erythrocyte antibody response and immunoglobulin synthesis in backcross and F2 progeny of mice genetically selected for "high" or "low" antibody synthesis. J Exp Med 1972, 136:790-798

32. Pandey JP, Luo Y, Elston RC, Wu Y, Hite Philp F, Astemborski J, Thomas DL, Netski DM: Immunoglobulin allotypes influence IgG antibody responses to hepatitis C virus envelope proteins E1 and E2. Hum Immunol 2008, 69:158-164.

33. Hoffman RW, Sharp GC, Irvin WS, Anderson SK, Hewett JE, Pandey JP: Association of immunoglobulin $\mathrm{Km}$ and $\mathrm{Gm}$ allotypes with specific antinuclear antibodies and disease susceptibility among connective tissue disease patients. Arthritis Rheum 1991, 34:453-458.

34. Kameda H, Pandey JP, Kaburaki J, Inoko H, Kuwana M: Immunoglobulin allotype gene polymorphisms in systemic sclerosis: interactive effect of MHC class II and Km genes on anticentromere antibody production. Ann Rheum Dis 1998, 57:366-370.

35. Pandey JP, Page GP, Silver RM, LeRoy EC, Bona CA: Anti-fibrillin-1 autoantibodies in systemic sclerosis are $\mathrm{Gm}$ and $\mathrm{Km}$ allotype restricted. Exp Clin Immunogenet 2001, 18:123-129.

36. Pertovaara M, Hurme M, Antonen J, Pasternack A, Pandey JP: Immunoglobulin KM and GM gene polymorphisms modify the clinical presentation of primary Sjögren's syndrome. J Rheumatol 2004, 31:2175-2180

37. O'Hanlon TP, Rider LG, Targoff IN, Malley JK, Pandey JP, Schiffenbauer A, Miller FW: Immunoglobulin gene polymorphisms and the idiopathic inflammatory myopathies: GM and KM profiles distinguish patients by age, race, clinical phenotypes and myositis autoantibodies. Arthritis Rheum 2008, 58:3239-3246.

38. Goldblatt D, Scadding GK, Lund VJ, Wade AM, Turner MW, Pandey JP: Association of $\mathrm{Gm}$ allotypes with the antibody response to the outer membrane proteins of a common upper respiratory tract organism, Moraxella catarrhalis. J Immunol 1994, 153:5316-5320.

39. Pandey JP, Shannon BT, Tsang KY, Fudenberg HH, Camblin JG: Heterozygosity at $\mathrm{Gm}$ loci associated with humoral immunity to osteosarcoma. J Exp Med 1982, 155:1228-1232.

40. Pandey JP, Nietert PJ, Mensdorff-Pouilly S, Klaamas K, Kurtenkov O: Immunoglobulin allotypes influence antibody responses to mucin 1 in patients with gastric cancer. Cancer Res 2008, 68:4442-4446.

41. Pandey JP, Nietert PJ, Klaamas K, Kurtenkov O: A genetic variant of immunoglobulin $\gamma 2$ is strongly associated with natural immunity to mucin 1 in patients with breast cancer. Cancer Immunol Immunother 2009, 58:2025-2029.

42. Pandey JP, Namboodiri AM, Kurtenkov O, Nietert PJ: Genetic regulation of antibody responses to human epidermal growth factor receptor 2 in breast cancer. Hum Immunol 2010, 71:1124-1127.

43. Pandey JP, Namboodiri AM, Kistner-Griffin E, Iwasaki M, Kasuga Y, Hamada GS, Tsugane S: Racially restricted contribution of immunoglobulin Fcy and Fcy receptor genotypes to humoral immunity to human epidermal growth factor receptor 2 in breast cancer. Clin Exp Immunol 2013, 171:273-277.

44. Morahan G, Berek C, Miller JFAP: An idiotypic determinant formed by both immunoglobulin constant and variable regions. Nature 1983, 301:720-722.

45. Casadevall A, Pirofski LA: A new synthesis for antibody-mediated immunity. Nat Immunol 2012, 13:21-28

46. Torres M, Fernandez-Fuentes N, Fiser A, Casadevall A: The immunoglobulin heavy chain constant region affects kinetic and thermodynamic parameters of antibody variable region interactions with antigen J Biol Chem 2007, 282:13917-13927.

47. Stockmeyer B, Valerius $T$, Repp IR, Heijnen IA, Bühring $H J$, Deo YM, Kalden $J R$, Gramatzki M, van de Winkel JG: Preclinical studies with FcyR bispecific antibodies and granulocyte colony-stimulating factor-primed neutrophils as effector cells against HER-2/neu over expressing breast cancer. Cancer Res 1997, 57:696-701.

48. Musolino A, Naldi N, Bortesi B, Pezzuolo D, Capelletti M, Missale G, Laccabue D, Zerbini A, Camisa R, Bisagni G, Neri TM, Ardizzoni A: Immunoglobulin G fragment $C$ receptor polymorphisms and clinical efficacy of trastuzumabbased therapy in patients with HER-2/neu-positive metastatic breast cancer. J Clin Oncol 2008, 26:1789-1796.

49. Bibeau F, Lopez-Crapez E, Di Fiore F, Thezenas S, Ychou M, Blanchard F, Lamy A, Penault-Llorca F, Frébourg T, Michel P, Sabourin JC, BoissièreMichot F: Impact of FcyRIla-FcyRIIla polymorphisms and KRAS mutations on the clinical outcome of patients with metastatic colorectal cancer treated with cetuximab plus irinotecan. J Clin Oncol 2009, 27:1122-1129.

50. Taylor RJ, Chan SL, Wood A, Voskens CJ, Wolf JS, Lin W, Chapoval A, Schulze DH, Tian G, Strome SE: FcgammaRIlla polymorphisms and cetuximab induced cytotoxicity in squamous cell carcinoma of the head and neck. Cancer Immunol Immunother 2009, 58:997-1006.

51. Namboodiri AM, Pandey JP: Differential inhibition of trastuzumab and cetuximab induced cytotoxicity of cancer cells by lgG1 expressing different GM allotypes. Clin Exp Immunol 2011, 166:361-365.

52. Lazar GA, Dang W, Karki S, Vafa O, Peng JS, Hyun L, Chan C, Chung HS, Eivazi A, Yoder SC, Vielmetter J, Carmichael DF, Hayes RJ, Dahiyat BI: Engineered antibody Fc variants with enhanced effector function. Proc Natl Acad Sci USA 2006, 103:4005-4010.

53. Weiner $L M$, Surana $R$, Wang S: Monoclonal antibodies: versatile platforms for cancer immunotherapy. Nat Rev Immunol 2010, 10:317-327.

54. Weiner LM, Murray JC, Shuptrine CW: Antibody-based immunotherapy of cancer. Cell 2012, 148:1081-1084.

55. Brüggemann M, Williams GT, Bindon $\mathrm{Cl}$, Clark MR, Walker MR, Jefferis $\mathrm{R}$ Waldmann $H$, Neuberger MS: Comparison of the effector functions of human immunoglobulins using a matched set of chimeric antibodies. J Exp Med 1987, 166:1351-1361. 
56. Dziurzynski K, Chang SM, Heimberger AB, Kalejta RF, McGregor Dallas SR, Smit M, Soroceanu L, Cobbs CS: HCMV and Gliomas Symposium: Consensus on the role of human cytomegalovirus in glioblastoma. Neuro-Oncol 2012, 14:246-255.

57. Atalay R, Zimmermann A, Wagner M, Borst E, Benz C, Messerle M, Hengel H: Identification and expression of human cytomegalovirus transcription units coding for two distinct Fcgamma receptor homologs. J Virol 2002, 76:8596-8608

58. Namboodiri AM, Pandey JP: The human cytomegalovirus TRL11/IRL11encoded FcyR binds differentially to allelic variants of immunoglobulin G1. Arch Virol 2011, 156:907-910.

59 Atherton A, Armour KL, Bell S, Minson AC, Clark MR: The herpes simplex virus type $1 \mathrm{Fc}$ receptor discriminates between $\lg \mathrm{G} 1$ allotypes. Eur J Immunol 2000, 30:2540-2547.

60. Namboodiri AM, Budkowska A, Nietert PJ, Pandey JP: Fcy receptor-like hepatitis $\mathrm{C}$ virus core protein binds differentially to $\lg \mathrm{G}$ of discordant $\mathrm{Fc}$ (GM) genotypes. Mol Immunol 2007, 44:3805-3808.

61. Namboodiri AM, Nietert PJ, Pandey JP: Hepatitis C virus core protein discriminates between the two IgG2 allotypes. Viral Immunol 2008, 21:273-276

62. Maillard P, Lavergne JP, Siberil S, Faure G, Roohvand F, Petres S, Teillaud JL, Budkowska A: Fcy receptor-like activity of hepatitis $\mathrm{C}$ virus core protein. J Biol Chem 2004, 279:2430-2437.

63. Schmidt $\mathrm{M}$, et al: A comprehensive analysis of human gene expression profiles identifies stromal immunoglobulin kappa $\mathrm{C}$ as a compatible prognostic marker in human solid tumors. Clin Cancer Res 2012, 18:2695-2703.

64. Ockhuizen T, Pandey JP, Veltri RW, Arlen M, Fudenberg HH: Immunoglobulin allotypes in patients with squamous cell carcinoma of the head and neck. Cancer 1982, 49:2021-2024.

65. Czerwinski M, Siemaszko D, Siegel DL, Spitalnik SL: Only selected light chains combine with a given heavy chain to confer specificity for a model glycopeptide antigen. J Immunol 1998, 160:4406-4417.

66. Primi D, Drapier AM, Cazenave PA: Highly preferential VH-VL pairing in normal $B$ cells results in antigen-independent selection of the available repertoire. J Immunol 1987, 138:1607-1612.

67. Biggar RJ, Pandey JP, Henle W, Nkrumah FK, Levine PH: Humoral immune response to Epstein-Barr virus antigens and immunoglobulin allotypes in African Burkitt lymphoma patients. Int J Cancer 1984, 33:577-580.

68. Pandey JP, Baker CJ, Kasper DL, Fudenberg HH: Two unlinked genetic loci interact to control the human immune response to type III group B streptococcal antigen. J Immunogenet 1984, 11:159-163.

69. Etto TL, Stewart LA, Muirhead J, Bailey M, Schwarer AP: Kappa immunoglobulin light chain polymorphisms and survival after allogeneic transplantation for B-cell malignancies: a potential graft-vs-leukaemia target. Tissue Antigens 2007, 69:56-61.

70. Fudenberg HH, Fudenberg BR: Antibody to hereditary human gammaglobulin $(\mathrm{Gm})$ factor resulting from maternal-fetal incompatibility. Science 1964, 145:170-171.

doi:10.1186/2162-3619-2-6

Cite this article as: Pandey and Li: The forgotten tale of immunoglobulin allotypes in cancer risk and treatment. Experimental Hematology \& Oncology 2013 2:6.

\section{Submit your next manuscript to BioMed Central and take full advantage of:}

- Convenient online submission

- Thorough peer review

- No space constraints or color figure charges

- Immediate publication on acceptance

- Inclusion in PubMed, CAS, Scopus and Google Scholar

- Research which is freely available for redistribution 